\title{
Pembelajaran Inkuiri Terbimbing Berbasis Pratikum Pada Topik Pengukuran Untuk Meningkatkan Penguasaan Konsep dan Keterampilan Proses Sains Siswa SMP
}

\author{
Mahrun $^{1}$, Anna Permanasari ${ }^{2}$, Leny Heliawati ${ }^{3}$ \\ ${ }^{1}$ Mahasiswa Pendidikan IPA,Universitas Pakuan \\ ${ }^{2}$ Pendidikan IPA, Universitas Pendidikan Indonesia \\ ${ }^{3}$ Pendidikan IPA, Universitas Pakuan \\ Email: mahrunspd@gmail.com
}

\begin{abstract}
Abstrak: Penelitian kuasi eksperimen ini bertujuan untuk mengimplementasikan pembelajaran inkuiri terbimbing berbasis pratikum untuk meningkatkan penguasaan konsep dan keterampilan proses sains siswa pada topik pengukuran. Sebanyak 83 siswa SMP Kelas I terlibat dalam penelitian ini. Subjek penelitian dikelompokkan dalam kelompok eksperimen dan kelompok kontrol. Kelompok eksperimen mendapat perlakuan pembelajaran inkuiri berbasis peratikum sedangkan kelompok kontrol mendapat perlakuan pembelajaran berbasis pratikum. Penelitian ini menggunakan instrumen pilihan ganda untuk menjaring penguasan konsep siswa, sedangkan keterampilan proses sains dijaring dengan menggunakan tes esay. Hasil analisis menunjukkan bahwa pembelajaran inkuiri terbimbing berbasis praktikum pada topik penguran dapat meningkatkan penguasaan konsep dan Keterampilan Proses Sains (KPS) siswa. Peningkatan penguasaan konsep untuk kelas eksperimen adalah $54.58 \%$ sedangkan kelas kontrol adalah 26.60\%. Peningkatan Keterampilan Proses Sains (KPS) pada kelas eksperimen sebesar $67.80 \%$ dengan kategori tinggi, sedangkan Keterampilan Proses Sains (KPS) kelas kontrol adalah $27.25 \%$ dengan katerogi sedang. Hasil analisis juga menunjukkan bahwa terdapat korelasi positif antara penguasaan konsep dan Keterampilan Proses Sains (KPS). Siswa juga memberikan tanggapan positif terhadap impelementasi pembelajaran inkuiri terbimbing berbasis praktikum.
\end{abstract}

Kata Kunci: Pembelajaran Inkuiri, Pratikum, Penguasaan Konsep, Keterampilan Proses Sains

\section{PENDAHULUAN}

Pendidikan IPA pada dasarnya berkaitan dengan cara mencari tahu tentang alam secara sistematis, sehingga memahami IPA bukan hanya penguasaan kumpulan pengetahuan yang berupa fakta-fakta, konsep-konsep, atau prinsipprinsip saja tetapi juga memahami bagaimana proses penemuan IPA. Pendidikan IPA diharapkan dapat menjadi wahana bagi peserta didik untuk mempelajari diri sendiri dan alam sekitar, serta prospek pengembangan lebih lanjut dalam menerapkannya di dalam kehidupan sehari-hari. Pencapaian tujuan pendidikan 
IPA dapat dilakukan dalam lingkup yang lebih kecil, yaitu dalam pembelajaran IPA di kelas.

Proses pembelajaran inkuiri di SMP dapat dilakukan dengan dua cara, yaitu inkuiri bebas dan inkuiri terbimbing. Inkuiri terbimbing merupakan suatu cara yang efektif untuk membuat variasi suasana pola pembelajaran kelas. Pembelajaran inkuiri terbimbing merupakan pembelajaran kelompok dimana siswa diberi kesempatan untuk berfikir mandiri dan saling membantu dengan teman yang lain. Dalam pembelajaran inkuiri terbimbing, guru membimbing siswa untuk memiliki tanggung jawab individu dan tanggung jawab dalam kelompok atau pasangannya. Hal ini memberikan makna bahwa inkuiri terbimbing merupakan penyelesaian dan membangun keterampilan proses sains siswa.

Pembelajaran inkuiri dibentuk atas dasar “discovery”, sebab seorang siswa harus menggunakan kemampuan penemuannya dan kemampuan lainnya. Dalam inkuiri, seorang bertindak sebagai seorang ilmuwan (scientist), melakukan eksperimen, dan melakukan proses mental (berinkuiri) melalui langkah-langkah sebagai berikut: 1) mengajukan pertanyaan-pertanyaan tentang gejala alami, 2) merumuskan masalah-masalah, 3) merumuskan hipotesis-hipotesis, 4) merancang pendekatan investigatif yang meliputi ekseperimen, 5) melaksanakan eksperimen, 6) mensitesiskan pengetahuan, dan 7) memiliki sikap ilmiah, antara lain objektif, ingin tahu, keterbukaan, menginginkan dan menghormati model-model teoritis, setra bertanggung jawab (Hamalik, 2008).

Beberapa penelitian terkait penerapan pembelajaran inkuiri dalam meningkatkan penguasaan konsep dan keterampilan proses sains siswa di antaranya, Ulpiyana (2014), penelitian dilakukan dalam hal penerapan pembelajaran inkuiri untuk meningkatkan penguasaan konsep dan kemampuan berinkuiri siswa pada topik sifat larutan penyangga, pada hasil wawancara menunjukkan informasi bahwa pembelajaran inkuiri sangat jarang diterapkan dalam kelas dan merupakan hal yang baru bagi siswa, sedangkan pada hasil observasinya selama proses pembelajaran di kelas eksperimen terdapat empat dari lima konten pembelajaran yang mengarah pada penemuan konsep terfasilitasi oleh guru. Selain itu juga telah diteliti model pembelajaran yang mirip pembelajaran inkuiri dalam meningkatkan penguasaan konsep, yaitu pembelajaran IPA menggunakan pendekatan inkuiri terbimbing melalui metode eksperimen dan demonstrasi ditinjau dari kemampua analisis dan sikap ilmiah siswa memiliki dampak yang baik terhadap prestasi belajar siswa, karna secara garis besar mampu mendapatkan nilai diatas KKM sekolah (Sayekti, 2012). Disimpulkan oleh Ongowo \& Indoshi, (2013) hasil penelitiannya menunjukkan bahwa ada persentase lebih tinggi dari keterampilan proses sains dasar dibandingkan keterampilan proses sains yang terintegrasi. 
Artikel ini bertujuan untuk mendeskripsikan implementasi pembelajaran inkuiri berbasis pratikum untuk meningkatkan keterampilan proses sains dan penguasan konsep siswa.

\section{METODE}

Penelitian ini menggunakan metode kuasi eksperimen (eksperimen semu) dengan desain non equivalen Pretest-Posttest Control Group Design (Sugiyono, 2013). Karakteristik metode kuasi eksperimen ditandai dengan adanya kelompok eksperimen dan kelompok kontrol yang sama-sama diberikan pretest dan posttest. Instrument pada saat pretest dan posttest sama, tetapi kelas eksperimen dan kontrol mendapatkan perlakuan yang berbeda (Fraenkel, 2012). Kelas eksperimen akan diberikan perlakuan pembelajaran dengan pendekatan inkuiri terbimbing (guided inquiry) berbasis praktikum, sedangkan kelas kontrol melaksanakan kegiatan pembelajaran berbasis praktikum tanpa inkuiri (inkuiri bebas).

Intrumen pilihan ganda digunakan untuk menilai penguasan konsep dan tes esay digunakan untuk menilai keterampilan proses sains siswa. Tes hasil penguasaan konsep dan keterampilan proses sains siswa dianalisis dengan menggunakan analisis kuantitatif. Peningkatan penguasan konsep dan keterampilan proses sains ditunjukkan dengan nilai gain pada masing-masing kelompok, baik kelompok eksperimen dan kelompok kontrol.

\section{HASIL DAN PEMBAHASAN}

\section{a. Penguasan Konsep}

Seluruh data penelitian prettes-posttest tes penguasaan konsep siswa kelas kontrol dan kelas eksperimen. .Secara umum deskripsi hasil belajar siswa untuk penguasaan konsep pada kelas kontrol dan kelas eksperimen, pada nilai pretest dan nilai postest dapat dilahat pada Tabel 1.1

Tabel 1.1 Peguasan Konsep Siswa

\begin{tabular}{|c|c|c|c|c|c|}
\hline \multirow[b]{2}{*}{ Kelas } & \multirow{2}{*}{$\begin{array}{l}\text { Parameter } \\
\text { Statistik }\end{array}$} & \multicolumn{2}{|c|}{ Nilai } & \multirow{2}{*}{$\begin{array}{c}(\%) \\
\text { N-Gain }\end{array}$} & \multirow[b]{2}{*}{ Kategori } \\
\hline & & Pretes & Postes & & \\
\hline \multirow{2}{*}{ Kontrol } & Jumlah siswa & 42 & 42 & \multirow{2}{*}{26.60} & \multirow{2}{*}{ Rendah } \\
\hline & Rata-rata & 38.41 & 55.85 & & \\
\hline \multirow{2}{*}{ Eksperimen } & Jumlah siswa & 41 & 41 & \multirow{2}{*}{54.58} & \multirow{2}{*}{ Sedang } \\
\hline & Rata-rata & 49.02 & 76.59 & & \\
\hline
\end{tabular}

Data hasil pengolahan tes awal, tes akhir dan N-gain yang dinormalisasi untuk penguasaan konsep siswa pada materi pengukuran kelas kontrol dan kelas eksperimen. Diagram perbandingan rata-rata nilai pritest-postest dan N-gain yang dinormalisasi untuk penguasaan konsep pada meteri pengukuran antara kelas kontrol dan kelas eksperimen ditunjukkan dalam diagram pada Gambar 1.1. 


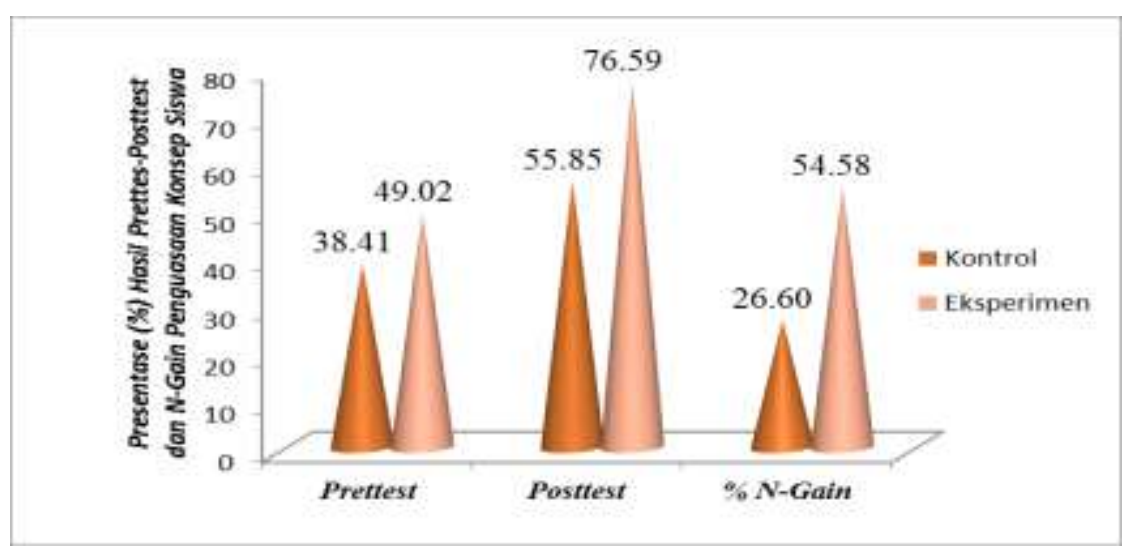

Gambar 1.1

Perbandingan Presentase Prettest-Posttest dan N-Gain Penguasaan Konsep Siswa Kelas Kontrol dan Kelas Eksperimen

Berdasarkan Gambar 1.1. di atas presentase rata-rata nilai pretest-posttest kelas eksperimen sebesar $62.81 \%$ dan kelas kontrol $47.13 \%$. Selanjutnya presentase rata-rata $\mathrm{N}$-gain pada kelas eksperimen dan kelas kontrol sebesar $40.59 \%$. Rata-rata nilai prettest penguasaan konsep siswa pada kelas eksperimen sebesar $49.02 \%$ dan kelas kontrol sebesar $38.41 \%$, sedangkan rata-rata nilai posttest kelas eksperimen sebesar $76.59 \%$ dan kelas kontrol sebesar $55.85 \%$. Lebih lanjut presentase rata-rata $\mathrm{N}$-gain yang dinormalisasi kelas eksperimen sebesar $54.58 \%$ dan kelas kontrol sebesar $26.60 \%$. Hal tersebut menunjukkan bahwa ada perbedaan peningkatan penguasaan konsep siswa yang mempelajari pengukuran dengan menggunakan pendekatan inkuiri terbimbing berbasis praktikum dibandingkan dengan peningkatan penguasaan konsep siswa yang mempelajari topik pengukuran berbasis praktikum dengan menggunakan pendekatan inkuiri lepas atau tanpa inkuiri.

Setelah diperoleh data peningkatan penguasaan konsep terkait dengan normalitas dan homogenitas maka selanjutnya dilakukan uji perbedaan dua rerata (uji hipotesis). Dengan menggunakan Independent Samples Tes untuk prettest dan non paremetrik yaitu dengan uji Mann-whitnye pada hasil posttest. Hasil pengujian selengkapnya dapat dilihat pada Tabel 1.2.

Tabel 1.2 Hasil Uji Perbedaan Rata-Rata Penguasaan Konsep Siswa Pada Kelas Kontrol dan Kelas Eksperimen

\begin{tabular}{|c|c|c|}
\hline Sumber Data & P-Volue & Kesimpulan \\
\hline Pretes & 0.102 & Perbedaan tidak signifikan \\
\hline Postes & 0.000 & Perbedaan secara signifikkan \\
\hline
\end{tabular}


Berdasarkan Tabel 1.2 di atas dapat disimpulkan bahwa pada hasil pretest signifikansinya $<0,05$, maka dapat dikatakan bahwa ada perbedaan yang signifikan penguasaan konsep siswa antara kelas eksperimen dan kelas kontrol sebelum diberikan perlakuan pembelajaran inkuiri terbimbing berbasis praktikum di kelas eksperimen, dan inkuiri lepas atau tanpa inkui di kelas kontrol. Selain itu juga untuk hasil postest karena tingkat signifikansinya $<0.05$, maka dapat dikatakan bahwa terdapat perbedaan secara signifikan dalam penguasaan konsep antara siswa kelas eksperimen dengan kelas kontrol setelah pelaksanaan pembelajaran.

Topik pengukuran yang diajarkan di kelas kontrol dan eksperimen terdiri dari beberapa sub konsep yaitu pengertian pengukuran, pengukuran besaran pokok, dan pengukuran besaran turunan. Untuk mengukur penguasaan konsep siswa pada sub konsep tersebut digunakan tes pilihan ganda sebanyak 20 soal. Tes menggunakan soal yang sama diberikan kepada kedua kelas yang masing-masing jumlah siswa, kelas kontrol 42 orang siswa sedangkan kelas eksperimen 41 orang siswa. Secara keseluruhan, data hasil prettest-posttest dan N-Gain dalam presentase untuk setiap sub konsep yang ada pada topik pengukuran ditunjukkan pada Tabel 4.7.

Tabel 1.3 Hasil Belajar Siaswa Pada Setiap Penguasaan Sub Konsep

\begin{tabular}{|l|c|c|c|c|c|c|}
\hline \multirow{2}{*}{\begin{tabular}{c}
\multirow{1}{*}{$\begin{array}{c}\text { Kub } \\
\text { Konsep }\end{array}$} \\
\cline { 2 - 5 }
\end{tabular}} & \multicolumn{2}{|c|}{ Kelas Kontrol } & \multicolumn{2}{c|}{\begin{tabular}{c}
\multicolumn{2}{c|}{ Kelas } \\
Eksperimen
\end{tabular}} & \multicolumn{2}{c|}{ N-Gain } \\
\cline { 2 - 6 } & Pretes & Postes & Pretes & Postes & $\begin{array}{c}\text { Kontrol } \\
(\%)\end{array}$ & $\begin{array}{c}\text { Eksperimen } \\
(\%)\end{array}$ \\
\hline $\begin{array}{l}\text { Pengertian } \\
\text { Pengukuran }\end{array}$ & 41.46 & 59.76 & 52.85 & 76.02 & 23.46 & 46.91 \\
\hline $\begin{array}{l}\text { Pengukuran } \\
\text { Besaran } \\
\text { Pokok }\end{array}$ & 42.68 & 59.51 & 54.88 & 78.54 & 22.54 & 50.08 \\
\hline $\begin{array}{l}\text { Pengukuran } \\
\text { Besaran } \\
\text { Turunan }\end{array}$ & 23.17 & 40.85 & 28.66 & 72.56 & 16.06 & 55.08 \\
\hline
\end{tabular}

Berdasarkan Tabel 1.3 di atas presentase perolehan nilai penguasaan setiap sub konsep pretest kelas eksperimen nelai tertinggi terjadi pada sub konsep pengukuran besaran pokok sebesar $54.88 \%$ dan nilai terendah ada pada sub konsep pengukuran besaran turunan sebesar $28.66 \%$ sedangkan presentase pretes penguasaan setiap sub konsep pada kelas kontrol nilai terbesar $42.86 \%$ pada sub konsep pengukuran besaran pokok sedangkan nilai terendah ada pad sub konsep pengukuran besaran turunan $22.62 \%$. Presentase postest pada kelas eksperimen 
nilai tertinggi ada pada sub konsep pengukuran besaran pokok sebesar $78.54 \%$ dan terendah ada pada sub konsep pengukuran besaran turunan sebesar $72.56 \%$, sedangkan presentase posttest kelas kontrol nilai tertinggi ada pada sub konsep pengukuran besaran pokok sebesar $59.92 \%$ dan terendah ada pada sub konsep pengukuran besaran turunan dengan nilai $22.62 \%$. Dengan demikian dapat di simpulkan dari uraian di atas bahwa ada tejadi pengingkatan penguaasaan konsep pada setiap sub konsep di kelas eksperimen dan kelas kontrol.

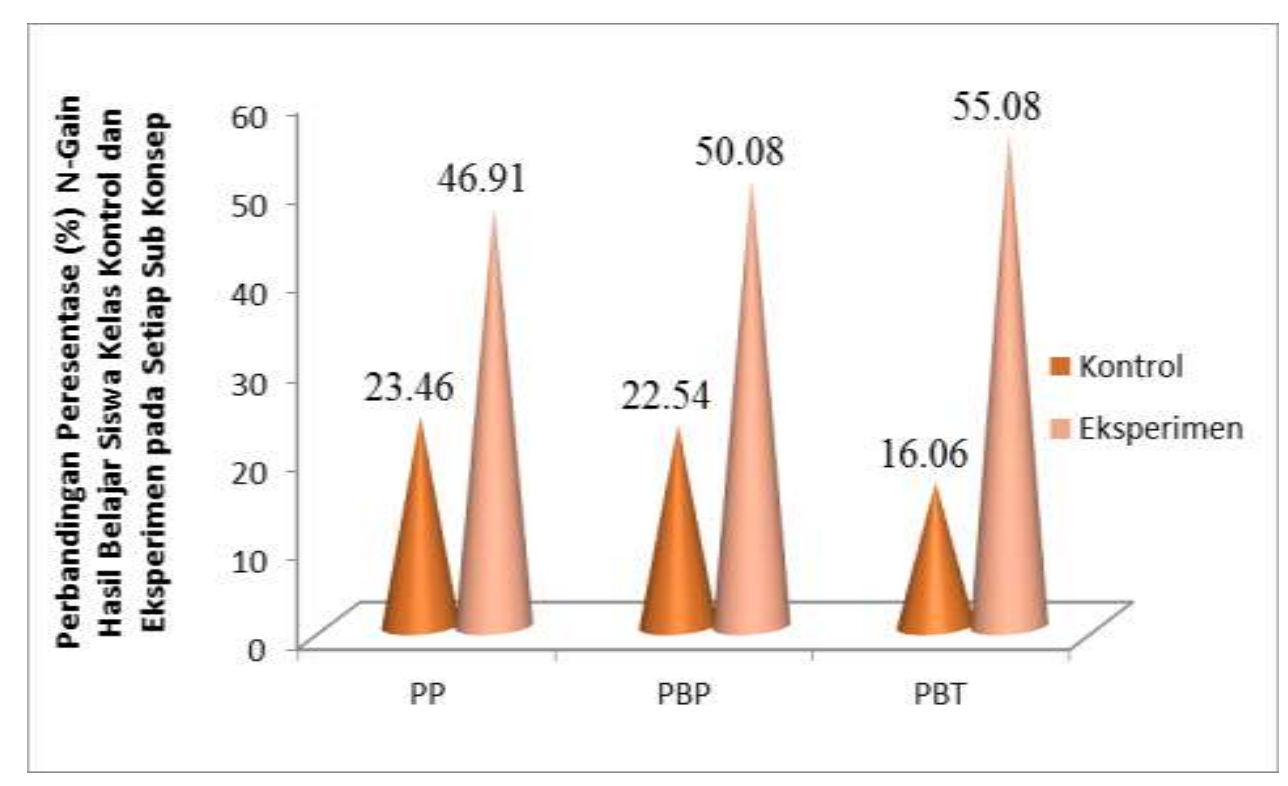

Gambar 1.2

Perbandingan Presentase N-Gain Penguasaan Konsep pada Setiap Sub Konsep

\section{Keterangan:}

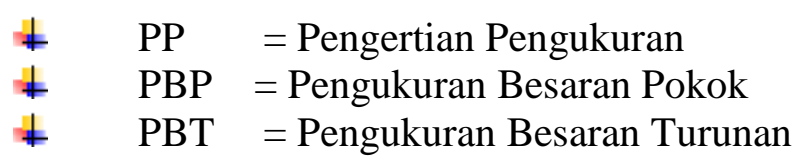

Berdasarkam Gambar 1.2 di atas nilai gain yang sudah dinormalisasi pada setiap penguasaan sub konsep kelas eksperimen memiliki presentase $\mathrm{N}$-gain yang lebih tinggi di bandingkan dengan kelas kontrol. Pada kelas eksperimen presentase N-Gain tertinggi ada pada sub konsep pengukuran besaran turunan yaitu $55.08 \%$, dan terendah ada pada sub konsep pengertian pengukuran sebesar 42.91\%. Pada kelas kontrol presentase N-Gain tertinggi ada pada sub konsep pengertian pengukuran sebesar $23.46 \%$ sedangkan terendah ada pada sub konsep pengukuran sebesar turunan sebesar $16.06 \%$. 


\section{b. Peningkatan Keterampilan Proses Sains Siswa.}

Diagram presentase perbandingan hasil pretest-postest dan gain yang dinormalisasi untuk keterampilan proses sains antara siswa kelas kontrol dan kelas eksperimen dapat dilihat pada Gambar. 1.3

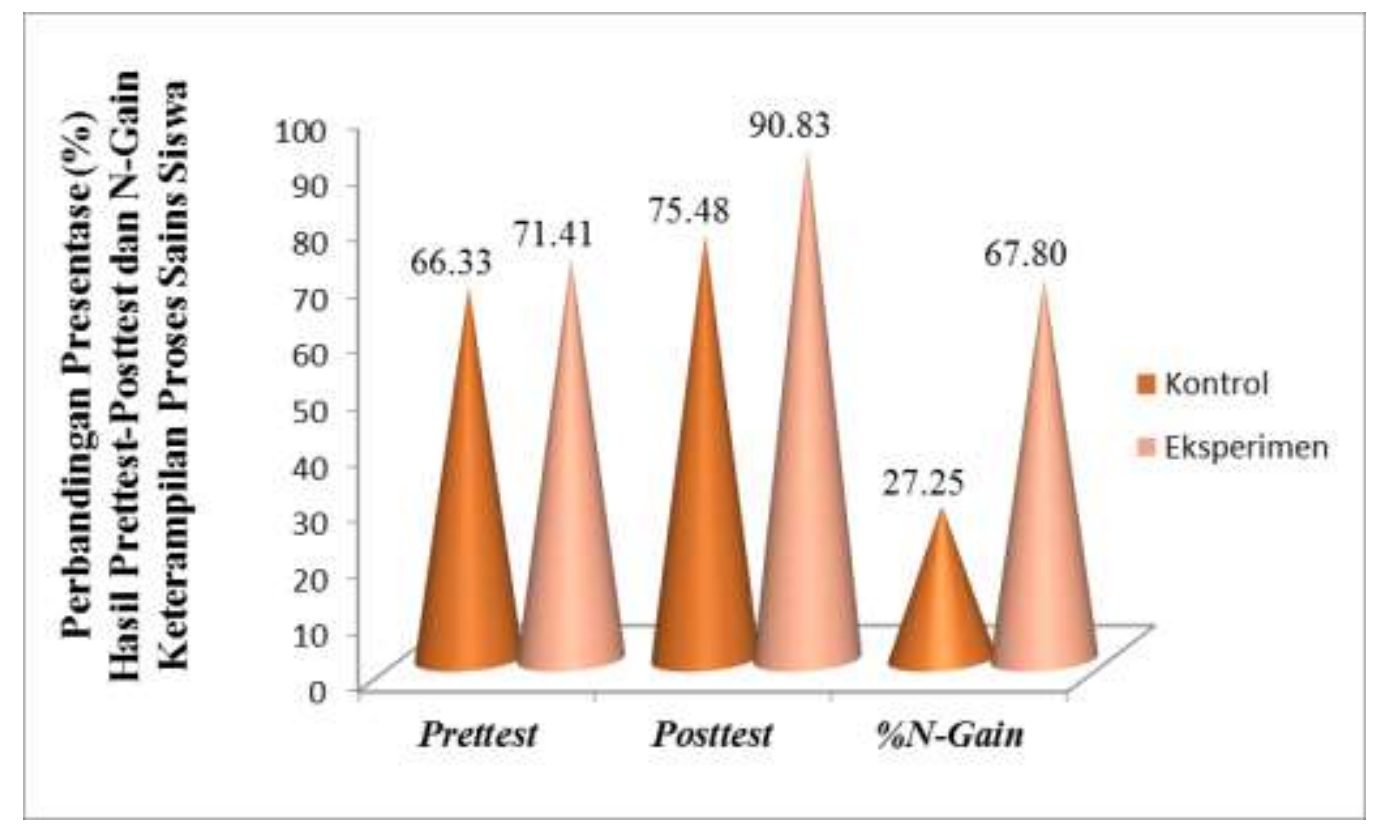

Gambar 1.3 Perbandingan Presentase Prettest-Postest dan Gain Keterampilan Proses Sains Siswa Kelas Eksperimen dan Kelas Kontrol

Berdasarkan Gambar 1.3 di atas presentase hasil prettest keterampilan proses sains siswa kelas eksperimen sebesar $71.41 \%$ dan kelas kontrol $66.33 \%$, sedangkan presentase hasil postest keterampilan proses sains siswa kelas eksperimen $90.83 \%$ dan kelas kontrol $75.48 \%$.

Presentase $\mathrm{N}$-gain yang dinormalisasi keterampilan proses sains siswa kelas kontrol sebesar $27.25 \%$ dan kelas eksperimen sebesar $67.80 \%$. Rata-rata gain yang dinormalisasi kelas kontrol termasuk kategori sedang dan kelas eksperimen termasuk kategori tinggi. Perbedaan rata-rata kategori gain yang dinormalisasi antara kelas eksperimen dan kontrol menunjukan adanya peningkata keterampilan proses sains siswa setelah pelaksanaan pembelajaran. Setelah diperoleh data keterampilan proses sains siswa pada topik pengukuran lewat pretest-postest dan ada yang berditribusi tidak normal maka perlu dilakukan uji mann whitney atau uji hipotesis pada hasip pretest-postest keterampilan proses sains siswa. Hasil pengujian selengkapnya dapat dilihat pada Tabel 1.4 
Tabel 1.4 Hasil Ujian Perbedaan Dua Rerata Keterampilan Proses Sains Siswa Pada Kelas Kontrol dan Kelas Eksperimen

\begin{tabular}{|c|c|c|}
\hline Sumber Data & $\boldsymbol{P}$-Volue & Kesimpulan \\
\hline Pretes & 0.325 & Berbeda tidak Signifikan \\
\hline Postes & 0.000 & Berbeda secara Signifika \\
\hline
\end{tabular}

Berdasarkan Tabel 1.4 di atas menunjukkan bahwa hasil uji nilai pretest signifikasinya $=0.325$, karena signifikasinya $>0.05$ maka dapat disimpulkan bahwa tidak ada perbedaan secara signifikan dalam ketampilan proses sains siswa antar kelas kontrol dan kelas eksperimen sebelum pelaksanaan pembelajaran inkuiri terbimbing berbasis praktikum. Begitu juga untuk hasil posttest diperoleh taraf signifikan 0.000 , karena signifikasinya $<0.05$ maka dapat disimpulkan bahwa berbeda secara signifikan dari keterampilan proses sains siswa setelah pelaksanaan pembelajaran inkuiri terbimbing berbasis praktikum di kelas eksperimen dan pembelajaran inkuiri lepas atau tanpa inkuiri di kelas kontrol.

Keterampilan proses sains yang dikaji dalam penelitian ini dibatasi pada beberapa indikator. Indikator keterampilan proses sains yang digunakan dalam penelitian ini adalah a) mengamati (observasi), b) interprestasi data, c) memprediksi, d) merencanakan percobaan, dan e) mengkomunikasikan. Data hasil pretest-postest setiap indikator keterampilan proses sains ditunjukkan pada Tabel 1.5

Tabel 1.5 Hasil Belajar Siswa Pada Setiap Indikator Keterampilan Proses Sains

Kelas Eksperimen dan Kelas Kontrol

\begin{tabular}{|l|l|c|c|}
\hline \multirow{2}{*}{ Indikator KPS } & \multicolumn{1}{|c|}{ Indikator Pembelajaran } & \multicolumn{2}{|c|}{ N-Gain } \\
\cline { 3 - 4 } & & $\begin{array}{c}\text { Kontrol } \\
(\%)\end{array}$ & $\begin{array}{c}\text { Eksperimen } \\
\text { (\%) }\end{array}$ \\
\hline Mengamati & $\begin{array}{l}\text { Menunjukan hasil pengamatan } \\
\text { yang benar }\end{array}$ & 35.12 & 88.62 \\
\hline $\begin{array}{l}\text { Menginterprestasi } \\
\text { data }\end{array}$ & $\begin{array}{l}\text { Menginterprestasikan hasil } \\
\text { pengukuran }\end{array}$ & 27.18 & 55.69 \\
\hline Memprediksi & $\begin{array}{l}\text { Memprediksi panjang dan berat } \\
\text { suatu benda dan alat ukur yang } \\
\text { digunakan }\end{array}$ & 14.48 & 36.79 \\
\hline $\begin{array}{l}\text { Merencanakan } \\
\text { petrcobaan }\end{array}$ & $\begin{array}{l}\text { Merencanakan percobaan } \\
\text { pengukuran pengukuran }\end{array}$ & 27.78 & 64.02 \\
\hline $\begin{array}{l}\text { Mengkomunikasi } \\
\text { kan }\end{array}$ & $\begin{array}{l}\text { Melaporkan data hasil } \\
\text { percobaan kedalam tabel }\end{array}$ & 27.18 & 73.37 \\
\hline
\end{tabular}

Berdasarkan Tabel 1.5 di atas presentase perolehan nilai keterempilan proses sains untuk prettest pada kelas eksperimen yang tertinggi diperoleh pada indikator mengkomunikasikan sebesar $73.17 \%$, dan terendah terdapat pada indikator merencanakan percobaan sebesar $67.32 \%$. Pada kelas kontrol perolehan 
presentase tertinggi pada saat prettest ada pada indikator mengkomunikasikan sebesar $67.62 \%$ dan terendah ada pada indikator mengamati sebesara $65.24 \%$.

Selanjutnya presentase perolehan hasil postest pada kelas eksperimen nilai tertinggi ada pada indikator mengamati sebesar $96.83 \%$ dan terendah terdapat pada indikator memprediksi sebesar $86.59 \%$. Pada kelas kontrol hasil postest tertinggi diperoleh pada indikator mengamati sebesar $77.86 \%$ dan terendah terdapat pada indikator memprediksi sebesar $71.90 \%$. Peningkatan keterampilan proses sains yang ditunjukkan pada presentase rata-rata Gain untuk tiap indikator keterampilan proses sains di tunjukkan pada Gambar 4.5.

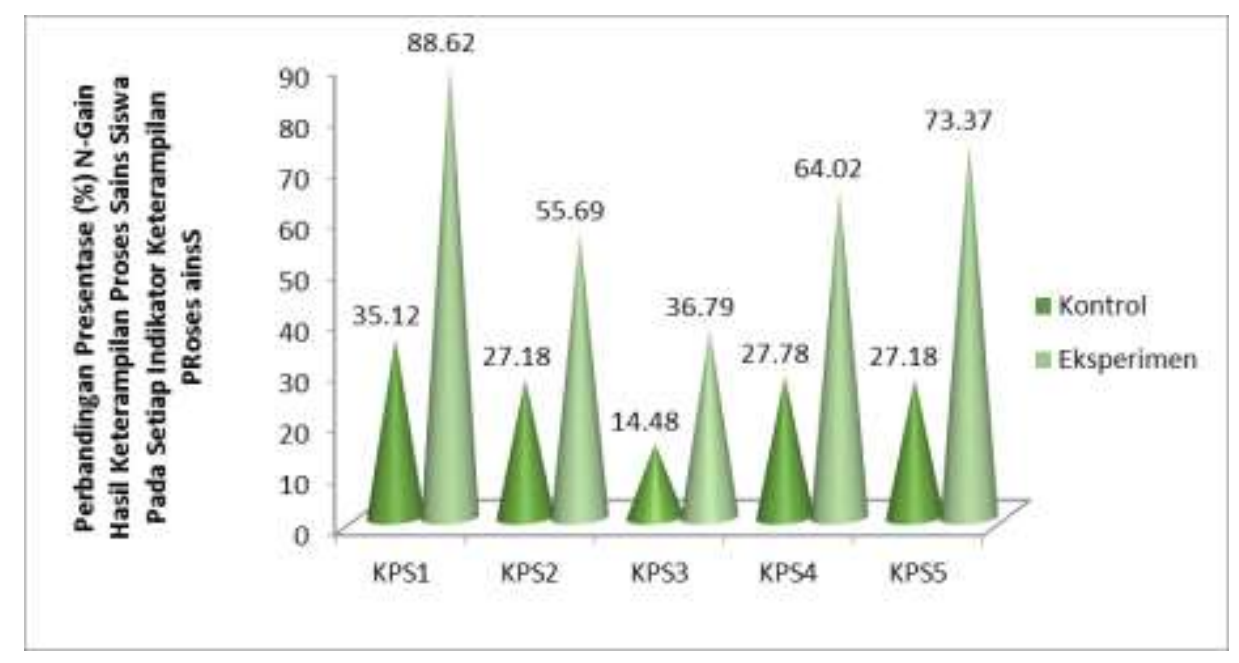

Gambar 1.4 Perbandingan Gain Setiap Indikator Keterampilan Proses Sains Siswa

\section{Keterangan:}

KPS $1 \quad$ : Keterampilan mengamati (Obsevasi)

KPS 2 : Keterampilan menginterprestasikan data

KPS 3 : Keterampilan memprediksi

KPS 4 : Keterampilan merencanakan percobaan

KPS 5 : Keterampilan mengkomunikasikan

Berdasarkan Gambar 1.4 di atas menunjukkan bahwa nilai presentase gain untuk keterampilan proses sains siswa kelas eksperimen lebih tinggi dibandingkan dengan kelas kontrol. Selisih tertinggi untuk presentase $\mathrm{N}$-gain antara kelas eksperimen dan kelas kontrol terdapat pada indikator mengamati (observasi) yaitu sebesar $88.62 \%$ sedangkan di kelas kontrol hanya sebesar $35.12 \%$.

Pada kelas eksperimen $\mathrm{N}$-gain tertinggi ada pada indikator mengamati (observasi) sebesar $88.62 \%$ dan terendah ada pada indikator memprediksi sebesar $36.79 \%$. sedangkan pada kelas kontrol perolehan presentase $\mathrm{N}$-gain tertinggi ada pada indikator mengamati (observasi) sebesar $35.12 \%$ dan terendah ada pada 
indikator memprediksi sebesar $14.48 \%$. Berdasarkan pengelolaan data yang dilakukan untuk mengetahui korelasi antara keterampilan proses sains dengan penguasaan konsep siswa diperoleh koefesien korelasi sebesar 0.680. Hasil uji korelasi pearson menunjukkan terdapat korelasi positif dan bernilai tinggi antara keterampilan proses sains dengan penguasaan konsep siswa.

\section{KESIMPULAN}

Pelaksanaan pembelajaran inkuiri terbimbing berbasis praktikum pada topik pengukuran secara signifikan dapat meningkatkan penguasaan konsep siswa dibandingkan dengan pendekatan pembelajaran konvensional. Pelaksanaan pembelajaran inkuiri terbimbing berbasis praktikum pada topik pengukuran secara signifikan dapat meningkatkan keterampilan proses sains siswa lebih besar daripada pendekatan konvensional atau tanpa inkuiri berbasis praktikum. Peningkata pada kelas kontrol terjadi dengan kategori sedang, sedangkan di kelas ekperimen terjadi dengan kategori tinggi. Keterampilan proses sains berkorelasi dengan penguasaan konsep siswa. Semakin tingginya keterampilan proses sains siswa, maka akan mempengaruhi penguasaan konsepnya menjadi semakin baik.

\section{REFERENSI}

Abungu. H, E., Okere \& Wachanga, S. 2014. The Effect of Science Process Skills Teaching Approach on Secondary School Students' Achievement in Chemistry in Nyando District, Kenya. Journal of Educational and Social Research, 4(6)

Arikunto. 2010. Dasar-Dasar Evaluasi Pendidikan (Edisi Revisi). Jakarta: Bumi Aksara.

Bloom, B.S. 2001. A Taxonomy for Learning, Teaching and Assesing. New York: Longman.

Chebii R., Wachanga, S \& Kiboss J. 2012. Effects of Science Process Skills Mastery Learning Approach on Students' Acquisition of Selected Chemistry Practical Skills in School. Scientific Research, 3(8), 1291-1296.

Erniwati S. 2014. Penerapan Pembelajaran Inkuiri Untuk Meningkatkan Keaktifan Dan Hasil Belajar Siswa pada materi Sistem Respirasi Di Kelas VIII SMPN 1 Paling Tengah. Jurnal Ilmiah Derap Pendidikan, 8, 104

Espinosa, A.C., Monterola, S.L \& Punzalan. A. 2013. Career-Oriented Performance Tasks in Chemistry: Effects on Students' Integrated Science Process Sk. Cypriot Journal of Educational Sciences, 8(2), 211-226.

Fraenkel, J.R., et.al. 2012. How to Design and Evaluate Receach In Education, 8th Edition. New York: Mc. Graw-Hill

Hamalik, O. 2008. Proses Belajar Mengajar. Jakarta: PT Bumi Aksara.

Hamalik, O. 2010. Perencanaan Pengajaran Berdasarkan pendekatan sistem. Jakarta: PT Bumi Aksara

Kadir. 2015. Statistika terapan Konsep, Contoh dan Analisa Data dengan Program SPSS/Lisrel dalam Penelitian. Jakarta: Rajawali Pers 
Kementrian Pendidikan dan Kebudayaan. 2014. Buku Guru Ilmu Pengetahuan Alam. Jakarta: Kementrian Pendidikan dan kebudayaan.

Matthew, M.B \& Kenneth, I. 2013. A Study on The Effects Of Guided Inquiry Teaching Method On Students Achievement In Logic. International Researchers, 2(1)

Ongowo, R.O. \& Indoshi, F.C. 2013. Science Process Skills in the Kenya Certificate of Secondary Education Biology Practical Examinations. Scientific Research, 4(11), 713-717

Safriani S. 2013. Penerapan Model Pembelajaran Berbasis Pengalaman Dengan Pendekatan Inkuiri Pada Materi Cahaya Untuk Meningkatkan Penguasaan Konsep Dan Keterampilan Proses Sains Siswa SMP. Tesis. SPS UPI: tidak diterbitkan

Sanjaya, W. 2006. Starategi Pembelajaran Berorientasi Standa Proses Pendidikan. Jakarta: Kencana 20

Sayekti, I.C., Surwanto \& Suparmi. 2012. Pembelajaran IPA Menggunakan Pendekatan Inkuiri Terbimbing Melalui Metode Eksperimen Dan Demonstrasi Ditinjau Dari Kemampua Analisis Dan Sikap Ilmiah Siswa. Jurnal Inkuiri, 1,142-153

Sugiyono. 2013. Metode Penelitian Pendidikan Pendekatan Kuantitantif, Kualitatif dan R\&D. Bandung: Alfabeta

Sukarno., Anna, P \& Ida, H. 2013. Science Teacher Understanding to Science Process Skills and Implications for Science Learning at Junior High School (Case Study in Jambi). International Journal of Science and Research

Ulpiyana A. 2014. Penerapan Pembelajaran Inkuiri Untuk Meningkatkan Pengguasaan Konsep Dan Kemampuan Berinkuiri siswa Pada Topik Sifat Larutan Penyangga. Riset Dan Praktik Pendidikan Kimia, 1, 101. 